\title{
Comparative Literature in Cooperation
}

\author{
Sebastian DONAT \\ \& Stephan PACKARD
}

\section{Cooperation}

IN PREPARATION FOR THIS ISSUE OF UNIVERSITÉ INVITÉE, we were asked to provide an introduction outlining methodological principles that could be said to characterize Comparative Literature at Munich University.

We quickly found that we could not and did not want to do so - not, that is, in the sense of a confession for a specific creed or denomination within literary studies, a binding epistemological approach to the relationships of truth and literature, or a shared vision of a common school or superior principle. Any attempt in this direction seemed to immediately set itself apart from the actual communalities of our and our colleagues' work and interests. While it might be observed from the outside that structuralism continues to play a large role in many of the studies pursued at Munich, this is a rewarding practice rather than an exclusive credo. As much as traditions of hermeneutics as well as deconstruction featured largely in the oeuvre of the institute's founder Hendrik Birus, neither ever operated as a manifesto that would turn it into a capital-lettered Program, nor into each other's embittered contradiction or even surprising validation. ${ }^{1}$ And if some of the individual contributions outlining research projects at Munich in this issue can be considered in groups that share some elements, such as phenomenological concepts adapted for literary studies, an extensive consideration of intertextuality in editing traditions and the problems of translation, or the ideas of triadic semiotics, these do not reflect the zeal of conversion but rather happy incidences of productive encounter and mutual cooperation.

On reflection, we have come to believe that if a common tendency exists that can characterize many of our efforts, it would be most proper to describe it not as a contended solution to the problems of literary theory, but as a dedication to a network of different disciplines, competences and faculties in tackling each problem. Not although but because any student of Comparative Literature should stand on the firm foundation of specific philological training and lingual capability, a recognition of the limits of isolated study and research soon becomes paramount to a responsible reading moving beyond contained scopes and connecting to further literatures, languages, traditions and disciplines. In some of the most engaging projects of the past and present, revelment in the diversity and disparity of differing philological, historical, philosophical and other disciplines informed and rewarded individual projects. In the following, we present two larger projects that have recently kept Munich's Comparative Literature Department busy and that may serve as examples for the specific provocations and opportunities afforded by this necessary priority of academic communication, mindful that interdisciplinary work accompanies its solutions with a host of new challenges, which are perhaps its own greatest reward. The knowledge of Comparative Literature, then, seems not so much to be stored in individual minds but rather to take place in communication.

\footnotetext{
${ }^{1}$ Cf. e.g. Hendrik Birus, « Hermeneutik und Strukturalismus. Eine kritische Rokonstruktion ihres Verhältnisses am Beispiels Schleiermachers und Jakobsons ", Roman Jakobsons Gedichtanalysen. Eine Herausforderng an die Philologien, eds. Hendrik Birus, Sebastian Donat and Burkhard Meyer-Sickendiek, Göttingen, Wallstein, 2003, pp. 11-37.
} 


\section{The German Edition of Roman Jakobson's Studies of Poetry}

It has been more than a quarter century since Roman Jakobson's collected poetological analyses were edited under the title Poetry of Grammar and Grammar of Poetry as the third volume of his Selected Writings (1981; with some additions in further volumes), and thus first comprehensively presented to a world-wide academic public. $^{2}$ Unfortunately, this monumental late work of one of literary structuralism's founders and central proponents had hitherto gone without its due attention, although some important but limited parts of the whole have been and continue to be the matter of intensive discussions in literary theory ${ }^{3}$ and have taken their place in the basic literary < toolbox >.

The various philologies' altogether (albeit in different ways) selective reception of Jakobson's work on poetry may be traced back to one ultimately contingent cause: Many of his essays and the poems they analyze are lingually inaccessible for a majority of potential readers. Jakobson wrote his analyses in no less than six languages - English, Russian, French, German, Polish, and Czech - and published them just so in the Selected Writings. The scope of analyzed verse text is considerably greater, adding Old Church Slavonic, Bulgarian, Italian, Japanese, Croatian, Modern Greek, Portuguese, Rumanian, Slovak and Slovenian. As very few translations have been hitherto available, those interested in Jakobson's analyses had to focus on whatever was closest to their own languages: English literature scholars on his studies on Sidney, Marvell, Blake, Yeats and especially Shakespeare, Romance scholars on his work on DuBellay, Baudelaire and Henri Rousseau (!), on Martin Codax and Pessoa, on Eminescu or on Dante, German literature scholars on the treatises on Hölderlin, Brecht and Klee (!), and so forth.

These three philologies suffice to show to what degree this purely lingually motivated selection of readers has made it all but impossible to gain adequate insight into the methods and potential of Jakobson's analyses. For the widely uninspired Shakespeare analysis with its clunkily mechanic program of inquiry, the methodologically comparatively immature and inarticulate study on Baudelaire's Les chats, and especially the biographically and psychologically reaching treatise on Hölderlin's Die Aussicht are exceptions to a more general rule, which need to be considered among other, more < typical > analyses to be understood. This is true not only for the structuralist procedure itself, but also for the rank or representativity of the analyzed texts, a fact that becomes most obvious in Jakobson's work on German literature. ${ }^{4}$ Hölderlin's very late eight-liner Die Aussicht is clearly influenced by his progressive mental illness, the isolated didactic poem Wir sind sie is taken from Brecht's controversial and propagandistic Die Maßnahme, and Paul Klee's verses are themselves a result of Jakobson's transformation of an entry in Klee's diary. Considering this idiosyncratic choice of material, one might well be left with the false impression that the structuralist method can only be applied to a small set of specific and marginal texts, and not to recognized canonical poetry.

This problem had to become most prominent in those studies that work with literature across lingual and cultural borders. And so it is no surprise that the decisive impulse for a new edition of Jakobson's poetological studies to counter these difficulties came from Comparative Literature. Instigated by Hendrik Birus, founder and long-time President of the

\footnotetext{
${ }^{2}$ For the following, cf. Hendrik Birus and Sebastian Donat, "Vorbemerkung der Herausgeber », Roman Jakobson : Poesie der Grammatik und Grammatik der Poesie. Sämtliche Gedichtanalysen. Kommentierte deutsche Ausgabe, 2 vols, eds. Hendrik Birus and Sebastian Donat, Berlin and New York, Walter de Gruyter, 2007, vol. 1, pp. IX-XII.

${ }^{3}$ Cf. the volume produced by Munich's International Ph D Programme in Literature, Roman Jakobsons Gedichtanalysen (fn. 1).

${ }^{4}$ That these three essays have been published separately before showcases the danger of selective perception. Cf. Roman Jakobson, Hölderlin - Klee · Brecht. Zur Wortkunst dreier Gedichte, ed. Elmar Holenstein, Frankfurt/Main, Suhrkamp, 1976.
} 
Institute for Comparative Literature at Munich, the project kept literally all of the institute's employees busy for several years, as everyone from professors to student assistants functioned as co-editors, editing board, commentators, translators or proof-readers. But it was clear from the start that the project could only succeed in a close and broad cooperation with colleagues from many other philologies. For on the one hand, the goal had to be a complete presentation of Jakobson's poetology: No language, however ( exotic > it might seem to Western Europeans, should be excluded. On the other hand, the contents had to be made largely accessible for the German reader, necessitating extensive commentary for all essays by specialists for the individual literatures. The explicit aim was to offer not only a philological edition that double-checked and completed all references, transformed them to recent editions wherever possible, added minimal emendations in specific cases and pointed to a multitude of other analyses and reactions in academic discussion, but also to help readers approach each language, literature, and the person and oeuvre of each poet, by adding introductions and running commentary.

Munich's International Ph D Programme in Literature (founded 2001 by an essentially comparatist initiative), acted as a primary rallying point for this cooperation. The Progamme's first symposium in 2002 was dedicated to Roman Jakobson's poetology, and it was here that the decision was made to realize a complete German edition as a joint project. The work that was begun there soon included 43 specialists translating, editing and commenting the 46 individual texts, many but not all of whom are included in the Programme as either professor or graduate student; without this starting advantage, the enterprise would have likely proven impossible.

But the academic cooperation involved in the Jakobson edition reached further yet, both in space and in interdisciplinarity: A number of scholars from universities in Germany and abroad added their commentaries to individual analyses, and cultural and academic institutions ranging from the Museum of Modern Art in New York to the Polish National Library in Warsaw got involved along the way. The interdisciplinary character of Roman Jakobson's ouevre began and guaranteed an intensive communication between colleagues from the fields of literary theory and linguistics. It is only by their combined efforts that the linguistic and literary sophistication of Jakobson's text could be opened up to readers.

Cooperation by its very nature denotes diversity. Its enormous benefits could not curtail the completeness of the whole. Thus editors and editing board had to work on the formal and conceptual unification of the various contributions, while preserving each contributor's individual style. Several elements of the edition were designed to further its homogeneity and usability. In order to bring the egregiously polyglot analyses closer to German readers, all elements in foreign languages - from the analyzed poem through quotes from secondary literature to the titles of academic publications other than in German, English or French - received translations in addition to the rendered text in the original. An extensive glossary explaining the most important linguistic, poetological and metrical vocabularies relieved the pressure on the commentary to each essay and added another approach to their isolated and joint understanding. Finally, creating a complete and detailed register of names and topics proved to be an underestimated and painfully extensive task - one shared and alleviated by the late and missed computer philologist Giorgio Giacomazzi - but should make it easier to gain a complete view of the scope of Jakobson's subjects and to reconstruct or firstly discover internal connections.

An intensive cooperation between almost 50 scholars from different universities and disciplines, lasting for more than four years, and often interfering with everyday university work and forcing other projects to be put on hold, demands a high degree of communication skills, endurance and discipline from all participants. In retrospect, the best memories belong to those precious instances where some positive spirit of cooperation could prevail over the worst in effort and exhaustion. Whether that spirit sufficed to accomplish the set goals and to 
further the quality of the finished editions is up to the readers of Jakobson's Poesie der Grammatik und Grammatik der Poesie to decide.

\section{Seoul and Munich's Joint Ventures in Literary Studies}

Since spring 2004, the ongoing cooperation between the German Department at Seoul National University and the Institute for Comparative Literature at the Ludwig-MaximiliansUniversity of Munich is formalized in a contract of cooperation between both universities. The agreement emerged from several years' worth of previous communication and cooperation between individual researchers at both institutions, including especially Seoul's inestimable Young-Ae Chon and Munich's Hendrik Birus, and soon extending to other colleagues and many of their students, many of whom availed themselves from the resultant exchange program. In 2007, a DAAD grant made it possible to take this cooperation to the next level, by financing and increasing exchange programs for students as well as professors and by combining many of our shared interests in two new joint research projects, one dealing with Goethe's active and passive role in the processes of world literature, and the other with censorship and other forms of textual control in divided nations. Each of these realizes some of the core qualities of Comparative Literature both on its thematic and on its procedural level, connecting scholars and literatures through international and interdisciplinary communication to investigate literary communication across cultural and national borders.

The first of these traces Goethe's concept of Weltiteratur as one of the roots of Comparative Literature. ${ }^{5}$ Together with the contemporary disciplinary conception of Litterature comparée, the notion stands at the beginning of the discipline's tradition. An intensive exchange of ideas among its founders included Villemain and Ampère in Paris as well as Goethe in Weimar and was mostly carried out in their journals, Le Globe and Ueber Kunst und Althertum. It might best be understood with reference to their literary criticism as well as their orientations in the natural sciences. Litterature comparée beyond and across national and cultural borders and Goethe's projected world literature which tends towards (potentially global) international communication are at their core, cultural strategies that can be described by a detailed discourse analysis, with reference to economy, transport and communication technologies and not least medial processes of disclosure and acceleration following the end of the Napoleonic order in Europe. The flipside of this international communication can be seen in the isolation and self-determination of single national literatures.

Rather than an immeasurably vast or a qualitatively selective treasure of literary texts from all parts of the world, Goethe's formation of the term Weltliteratur denotes a version of international literary communication yet to be realized: A « universal, free interaction of all those alive at one time ", albeit " in constant reference to that what is left and known to us from the past $^{6} »$. This matter-of-fact and quite prosaic view connected to changes in technology and commerce at the beginning of the industrial age in Europe, gradually creating « the mind's desire to be included in the more or less free commerce of minds ${ }^{7}$ ». Beyond this

\footnotetext{
${ }^{5}$ The following descriptions profit greatly from the input of all contributing researchers. It is especially Roger Lüdeke whose writings informed the summary of the first research project.

${ }^{6}$ Johann Wolfgang Goethe, «Flüchtige Übersicht über die Kunst in Deutschland », Sämtliche Werke. Briefe, Tagebücher und Gespräche, eds. Friedmar Apel et al., Frankfurt a.M., Dt. Klassiker-Verlag, 1985-1999, I. Dept., vol. 18, pp. 807-810, here p. 809: An « allgemeine, freie Wechselwirkung aller zugleich Lebenden », " in steter Rücksicht auf das was uns vom Vergangenen übrig und bekannt ist ».

${ }^{7}$ Johann Wolfgang Goethe, « Vorwort zu Carlyles 〈Leben Schillers〉 », Sämtliche Werke. Briefe, Tagebücher und Gespräche, eds. Friedmar Apel et al., Frankfurt a.M., Dt. Klassiker-Verlag, 1985-1999, I. Dept., vol. 22, pp. 869-883, here p. 870: " der Geist [...] zu dem Verlangen, auch in den mehr oder weniger freyen geistigen Handelsverkehr mit aufgenommen zu werden ».
} 
original historical constellation, the concept of world literature has proven itself as one of Comparative Literature's key concepts, indispensable for a systematic demarcation of the discipline's subject matter ${ }^{8}$.

In Seoul and Munich, a reconstructed concept of world literature is to be tested and expanded by application to a set of present and culturally and politically relevant phenomena. What are the discursive, economical, political and technological or medial conditions of literature's current gradual internationalization in Korea and Germany? How are the foundations, implications and readings of the term changing as part of the social transformations in both countries in the late $20^{\text {th }}$ and early $21^{\text {st }}$ century? And which roles can and do Goethe and his texts still play, actively or passively, in literary translations and productions of world literature today?

The second larger research project focuses on Korea's and Germany's common experience as (currently or previously) divided nations. Among the multitude of mutually connected intralingual and intercultural topics shared by both nations, it is this comparable structure that can make some similarities recognizable in different shapes, and outline alternatives and possible leeway by putting the differences in relief: A field full of special chances and challenges for literary research. ${ }^{9}$ In our cooperation we pick the various functions of textual control in politically divided nations with a common language as our main subject matter. Including but going beyond the obviously central topic of censorship in the strict and explicit sense of an administrative and juridical tool of power, this research is as interested in economical and social mechanisms that influence the dispersion of texts and the structure of dispersed texts, among them such disparate phenomena as the protection of minors and reactions to new media.

How does the presence of the defined political other in the same language, how does the existence of printed, broadcast and internet material in a shared language from the other side of the divide affect the many aspects of literary communication? What juridical, economic and technological mechanisms control the permeability of the spatial and ideological border? What symmetries and asymmetries emerge in the reception of a shared literary history, in mutual literary criticism and in the description of the other side's treatment of literature, also and especially of the other side's censorship? And how is the other side itself constituted by literary processes?

At the centre of this project is an approach that considers censorship as readership and as a secondary literary criticism: ${ }^{10}$ On the one hand, any action that limits the production or dissemination of literary texts depends on a theory of reading and evaluating literature, ascribing qualities to texts and characterizing them as dissident, obscene, worthless or dangerous. In court, legislation and administration, censorship documents its process - often

\footnotetext{
${ }^{8}$ Cf. René Etiemble, « Faut-il réviser la notion de Weltliteratur? »[1964], Essais de littérature (vraiment) générale, 3rd edition Paris, Gallimard, 1975, pp. 15-36. Horst Rüdiger, «Literatur und Weltliteratur in der modernen Komparatistik », Weltliteratur und Volksliteratur, ed. Albert Schaefer, München, Beck, 1972, pp. 36-54. Zoran Konstantinović, Weltliteratur. Strukturen, Modelle, Systeme, Freiburg/Basel/Wien, Herder, 1979. Horst Steinmetz, «Weltliteratur. Umriß eines literaturgeschichtlichen Konzepts » [1985], Literatur und Geschichte. 4 Versuche, München, Iudicium, 1988, pp. 103-126 a. 136-141. György M. Vajda, « Methodologische Fragen einer Historiographie der Weltliteratur », Sensus Communis. Festschrift für Henry Remak, eds. János Riesz et al., Tübingen, Narr, 1986, pp. 193-202.

${ }^{9}$ Cf. e.g. Weiqun Gu, Conflicts of Divided Nations. The Cases of China and Korea, Westport, Praeger, 1995. Gregory Henderson et al., Divided Nations in a Divided World, New York, McCay, 1974. Kim Youn-Soo and Friedrich Büßen (eds.), Korea and Germany. The Status and Future Prospects of Divided Nations, Kiel, 1978, including: Kim Youn-Soo, «Die Deutsche Ostpolitik und die Koreanische Wiedervereinigungspolitik », pp. 104-123, and Rainer Wiechert, « Treaties between the Federal Republic of Germany and the German Democratic Republic - A Model for Divided Nations? », pp. 73-88.

10 Cf. Stephan Packard, "A Model of Textual Control: Misrepresenting Censorship ", Literature and Censorship, ed. Marijan Dovic, Ljubljana (forthcoming).
} 
in contradictory ways - by creating new texts. On the other hand, literary production will react and reflect textual control in its own effective and aesthetic structures. Corresponding phenomena range from the difficult ambiguities of texts conscious of the danger of censorship, from strategies of avoidance and Aesopic styles and genres, to the positive addressation toward specific readerships.

The format for both research projects is characterized by numerous exchanges of students on the pre- and post-gradual level, each spending a year at their host institution and participating in seminars, tutoring and language courses, as well as professors, joining in workshops and combined seminars in Korea and Germany. It is especially in the differing styles in teaching, research and academic discourse that the cooperation has been educating and rewarding beyond its specific research topics and its opportunities for interlingual studies. The two first workshops in Seoul in October 2007 and in Munich in January 2008, each dedicated to one of the two main research topics, have provided opportunities for intensive discussion on several specific problems: These include, among others, the phenomenon of evoked polyglotism in poetic texts through pseudotranslation that rhetorically mimics the otherness of foreign languages (Brigitte Rath); flipsides of world literature, exemplified by Georg Friedrich Daumer's Hafis poems and their Russian reception (Sebastian Donat); lyrical reflections upon Germany as a divided nation, compared with Korean examples (Young-Ae Chon); the treatment of truth and its evidence in Philipp Roth's Riverside (Ihmku Kim); and the discourse of censorship and its modelling of membranes between divided nations (Stephan Packard). Both projects have also generated topics for highly auspicious graduate theses, and numerous publications have followed or are yet expected, proving the success of connecting not only Korean and German advances into current problems of literary theories, but focusing this cooperation on students as well as professors and teaching as well as research.

In the current semester, Munich sees our first combined seminar, taught by Young-Ae Chon, Sebastian Donat and Stephan Packard, and focusing on textual production and control in divided nations. Expanding the original concept to include different constellation of shared or divided political constructs, cultures, governments and languages, it covers related phenomena in Germany, Korea, Ireland, China, Taiwan, Russia, Ukraine, Norway and Denmark, and many more. This seminar also first showcases a new approach to seminar organisation that again emphasizes the concept of realizing the comparative aspect of a project by inducing communication among differing experts: each topic is presented and examined by a team of two or more students, including at least one specialist for the topic with (usually and preferably) a native speaker's access to texts and cultural traditions as well as philological knowledge of the involved literature, the cultural situation and its history, and one student who comes to the topic from the ( outside >, without a host of previous knowledge, and able to ask the questions and engage in comparisons that rarely suggest themselves to those closely acquainted with each subject. First results have been extremely promising, leading to engaging debate as well as productive research. Comparative Literature happens in these conversations, feeding of and into continued cooperation. 
Birus, Hendrik, " Hermeneutik und Strukturalismus. Eine kritische Rokonstruktion ihres Verhältnisses am Beispiels Schleiermachers und Jakobsons ", Roman Jakobsons Gedichtanalysen. Eine Herausforderng an die Philologien, eds. Hendrik Birus, Sebastian Donat and Burkhard Meyer-Sickendiek, Göttingen, Wallstein, 2003, pp. 11-37.

Birus, Hendrik and Sebastian Donat, "Vorbemerkung der Herausgeber ", Roman Jakobson : Poesie der Grammatik und Grammatik der Poesie. Sämtliche Gedichtanalysen. Kommentierte deutsche Ausgabe, 2 vols, eds. Hendrik Birus and Sebastian Donat, Berlin and New York, Walter de Gruyter, 2007, vol. 1, pp. IX-XII.

Etiemble, René, "Faut-il réviser la notion de Weltliteratur? »[1964], Essais de littérature (vraiment) générale, 3rd edition Paris, Gallimard, 1975, pp. 15-36.

Goethe, Johann Wolfgang, «Flüchtige Übersicht über die Kunst in Deutschland », Sämtliche Werke. Briefe, Tagebücher und Gespräche, eds. Friedmar Apel et al., Frankfurt a.M., Dt. Klassiker-Verlag, 1985-1999, I. Dept., vol. 18, pp. 807-810.

Goethe, Johann Wolfgang, « Vorwort zu Carlyles «Leben Schillers»», Sämtliche Werke. Briefe, Tagebücher und Gespräche, eds. Friedmar Apel et al., Frankfurt a.M., Dt. KlassikerVerlag, 1985-1999, I. Dept., vol. 22, pp. 869-883.

$\mathrm{Gu}$, Weiqun, Conflicts of Divided Nations. The Cases of China and Korea, Westport, Praeger, 1995.

Henderson, Gergory et al., Divided Nations in a Divided World, New York, McCay, 1974.

Jakobson, Roman, Hölderlin · Klee · Brecht. Zur Wortkunst dreier Gedichte, ed. Elmar Holenstein, Frankfurt/Main, Suhrkamp, 1976.

Konstantinović, Zoran, Weltliteratur. Strukturen, Modelle, Systeme, Freiburg/Basel/Wien, Herder, 1979.

Packard, Stephan, « A Model of Textual Control: Misrepresenting Censorship », Literature and Censorship, ed. Marijan Dovic, Ljubljana (forthcoming).

Rüdiger, Horst, "Literatur und Weltliteratur in der modernen Komparatistik », Weltliteratur und Volksliteratur, ed. Albert Schaefer, München, Beck, 1972, pp. 36-54.

Steinmetz, Horst, "Weltliteratur. Umriß eines literaturgeschichtlichen Konzepts » [1985], Literatur und Geschichte. 4 Versuche, München, Iudicium, 1988, pp. 103-126 a. 136-141.

Vajda, György M., " Methodologische Fragen einer Historiographie der Weltliteratur », Sensus Communis. Festschrift für Henry Remak, eds. János Riesz et al., Tübingen, Narr, 1986, pp. 193-202.

Youn-Soo, Kim and Friedrich Büßen (eds.), Korea and Germany. The Status and Future Prospects of Divided Nations, Kiel, 1978. 